\section{Michigan Technological

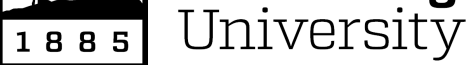

Michigan Technological University Digital Commons @ Michigan Tech

$12-1-2012$

\title{
Renewable Energy Policies and Programs in Nunavut: Perspectives from the Federal and Territorial Governments
}

Nicole C. McDonald

Queen's University

Joshua M. Pearce

Michigan Technological University

Follow this and additional works at: https://digitalcommons.mtu.edu/materials_fp

\section{Recommended Citation}

McDonald, Nicole C., \& Pearce, Joshua M. (2012). Renewable Energy Policies and Programs in Nunavut: Perspectives from the Federal and Territorial Governments. Arctic, 65(4), 465-475.

http://digitalcommons.mtu.edu/materials_fp/7 


\title{
Renewable Energy Policies and Programs in Nunavut: Perspectives from the Federal and Territorial Governments
}

\author{
NICOLE C. McDONALD ${ }^{1}$ and JOSHUA M. PEARCE ${ }^{2}$
}

(Received 18 July 2011; accepted in revised form 17 February 2012)

\begin{abstract}
Nunavut, the youngest Canadian territory, has developed a complete dependence on diesel-generated electricity over the last 50 years, which has led to environmental and economic stress on the territory. However, renewable energy technologies (RETs) could provide substantial electricity to communities, thereby reducing the use of diesel fuel. This study explored the perspectives of government policy-makers, northern energy consultants, and NGOs in order to understand the current status of renewable energy policy and development in Nunavut. Challenges identified included capacity gaps within the communities and government, bureaucratic barriers, barriers to financing RET projects, technological uncertainty, and development and infrastructure challenges. Opportunities explored include future RET funding options, strong renewable resources, increased community engagement through partnerships, and increased education opportunities. Respondents also discussed anticipated short- and long-term actions of each department. We recommend the establishment of a clear point of contact within the federal government: a group that would oversee all renewable energy policy and development in Nunavut. The group would also assess the full economic life cycle of renewable electricity to compare its true cost to that of unsubsidized, diesel-generated electricity.
\end{abstract}

Key words: Nunavut, renewable energy policy, photovoltaic system, wind energy, hydropower, solar energy, electricity

RÉSUMÉ. Le Nunavut, soit le plus jeune territoire du Canada, a développé une dépendance complète à l'électricité produite à partir du diesel ces 50 dernières années, ce qui engendre du stress environnemental et économique au sein du territoire. Cependant, les technologies des énergies renouvelables (TER) pourraient fournir de bonnes quantités d'électricité aux collectivités, ce qui réduirait la consommation de diesel. Cette étude s'est penchée sur les perspectives des preneurs de décisions des gouvernements, des consultants en énergie du nord et des organismes non gouvernementaux afin de parvenir à comprendre l'état actuel de la politique sur les énergies renouvelables et le développement de ces énergies au Nunavut. Parmi les défis ayant dû être relevés, notons la détermination des écarts de capacité entre les collectivités et les gouvernements, les obstacles bureaucratiques, les obstacles au financement de projets de TER, les incertitudes sur le plan technologique de même que les défis propres au développement et aux infrastructures. Nous avons donc exploré les options de financement futures en vue des TER, la mise au point de ressources renouvelables très viables, la participation accrue des collectivités grâce à l'établissement de partenariats de même que de plus grandes possibilités d'éducation. Les intervenants ont également discuté des mesures que devraient prendre chaque ministère à court terme et à long terme. Nous avons recommandé l'établissement d'un point de contact clair au gouvernement fédéral, soit un groupe qui surveillerait toute la politique et le développement des énergies renouvelables au Nunavut. Ce groupe évaluerait également le cycle de vie économique complet de l'électricité renouvelable afin de comparer son coût réel à celui de l'électricité non subventionnée produite à partir du diesel.

Mots clés : Nunavut, politique des énergies renouvelables, système photovoltaïque, énergie éolienne, énergie hydroélectrique, énergie solaire, électricité

Traduit pour la revue Arctic par Nicole Giguère.

\section{INTRODUCTION}

Nunavut, created in 1999 as Canada's third territory, is finding its own path towards self-governance. As part of this growing process, the territory is developing its unique range of extensive and encompassing government policies (GN, 2010a; Sivummut Economic Development Strategy Group,
2003), yet policies have yet to be developed for a number of areas (GN, 2010b). One such area is renewable energy, which requires a policy and program shift toward alternative energy solutions that are more sustainable, environmentally friendly, and economically viable (GN, 2007a, b, 2010b).

Over the last 50 years, as modernization and government pressure forced Inuit to abandon their nomadic lifestyle, they

${ }^{1}$ JD Candidate 2015, Faculty of Law, Queen's University, Kingston, Ontario K7L 3N6, Canada; 9nm@queensu.ca

${ }^{2}$ Corresponding author: Department of Materials Science \& Engineering and Department of Electrical \& Computer Engineering,

Michigan Technological University, 1400 Townsend Drive, Houghton, Michigan 49931-1295, USA; pearce@mtu.edu

(C) The Arctic Institute of North America 
began to live in settled communities and developed a strong dependence on imported fossil fuel for all of their energy needs, including transportation, heating, and electricity (GN, 2002, 2007a, b). However, while many other remote northern communities have begun to explore alternatives for electricity generation (GY, 2008; GNWT, 2009), such as solar photovoltaic technology, wind turbines, and hydropower, Nunavut has lagged behind and continues to maintain its use of diesel in all 25 communities (GN, 2007a, b).

To understand why renewable energy policy in Nunavut has been slow moving, despite enormous promise (McDonald et al., 2012), we interviewed key policy-makers in the federal and territorial governments, as well as consulting firms and NGOs that focus on northern renewable energy. Using data from these qualitative interviews, we provide a glimpse into the current and future departmental responsibilities for renewable energy in Nunavut. We explore existing challenges and opportunities with regard to developing renewable energy policy and programs in the territory and outline energy policy options that will help Nunavut to take advantage of the many environmental, social, and economic benefits of incorporating renewable energy technologies into its electricity supply mix.

\section{BACKGROUND}

\section{The Making of Nunavut}

Though Nunavut is Canada's newest territory, it is rich in culture and history, as Inuit have been living on the land for centuries (Crowe, 1991; GN, 2002, 2008a). The signing of the Nunavut Land Claims Agreement (NCLA, 1993) and the Nunavut Act (GC, 1993) changed the map of Canada's North.

The Nunavut Land Claims Agreement provided the Inuit of the Nunavut Settlement Area the right to use and occupy the lands, waters, and landfast ice within the region identified (NCLA, 1993). It laid the foundation for self-determination, recognizing the need to reverse past government policies that required Inuit to live in a way that conflicted with their traditional social, economic, and cultural values (Creery, 1983; Wonders, 2003).

Also signed in 1993 was the Nunavut Act, which provided for creating a new territory when it came into force on 1 April 1999 (GC, 1993; GN, 2008a). On that date, Nunavut (meaning 'our land') separated from the Northwest Territories to become Canada's third territory (Chung and Hyslop, 2008). It is now Canada's largest territory, encompassing one-fifth of the country's landmass (GN, 2008a). Nunavut's population in 2010 was about 32000 people, $85 \%$ of whom are Inuit (GN, 2008a, 2010a).

\section{Current Electricity Situation in Nunavut}

Since the territory of Nunavut is completely dependent on imported fossil fuel for its electricity needs (GN, 2007a, b), the high cost of transporting and purchasing fuel has created very high electricity rates in Nunavut communities, ranging from $52.39 \notin / \mathrm{kWh}$ in Iqaluit to $102.71 \phi / \mathrm{kWh}$ in Kugaruuk, compared to only $11 \mathrm{~d} / \mathrm{kWh}$ in Ontario (GNWT, 2008; CBC, 2011; QEC, 2011). These costs have created great economic stress on the Government of Nunavut (GN): about $20 \%$ of its annual budget is spent on energy (GN, $2007 \mathrm{a}, \mathrm{b})$. Moreover, the territorial government consistently subsidizes fuel purchases and electricity use to maintain viable electricity rates for residents. For example, the GN (2010a) estimated that in 2010-11, it would spend \$7.4 M on electricity subsidies - and close to $\$ 40 \mathrm{M}$ on all energy subsidies - through entitlement programs such as social assistance and social housing. The ongoing economic challenge of funding energy has likely limited the ability of the GN to address other issues, including housing shortages, inadequate health services, and under-funded education (NTI, 2008, 2010; GN, 2009, 2010a; Egeland et al., 2010).

Diesel-generated electricity has also taken its toll on the environment of Nunavut and the health of Nunavummiut. Diesel spills are often associated with the current energy situation, as all diesel fuel is imported into the territory by barge (GN, 2009). Such accidents have led to land degradation (GN, 2008a), a serious concern for the Inuit, who highly value and respect the land and environment (GN, 2008a). Moreover, in general, diesel generators are known to produce extensive emissions that have been linked to reduced air quality and negative health effects, although such a link has not yet been demonstrated in Nunavut (US EPA, 2002).

\section{Federal and Territorial Involvement in Nunavut's Energy Policy}

As discussions regarding devolution of rights continue, a number of federal and territorial departments remain involved in addressing Nunavut's energy situation (QEC, 2005; GN, 2008b, 2010c, d, e; GC, 2010; National Energy Board, 2011; AANDC, 2012).

Within the GN, the Department of Executive and Intergovernmental Affairs (DEIA) and the Department of Community and Government Services (DCGS) play active roles in developing energy policies and programs, while the Qulliq Energy Corporation (QEC), a regulated monopoly, provides all electricity to the territory (QEC, 2005). The Energy Secretariat, a division of the DEIA, is responsible for developing and coordinating a comprehensive energy policy to address the territory's dependence on imported fuel (GN, 2010c). At the same time, the DCGS focuses largely on developing energy efficiency programs, including the Nunavut Energy Management Program (NEMP), the Facility Energy Efficiency Review, the Nunavut Energy Retrofit Program, and Save 10 (GN, 2010d). In addition, the Nunavut Petroleum Products Division of the DCGS is responsible for the purchase, transportation, storage, and distribution of all petroleum products in Nunavut (GN, 2010e). 
A number of federal government departments are also involved in expanding the use of renewable energy technologies in Nunavut through funding programs. Aboriginal Affairs and Northern Development Canada (AANDC), formerly the Department of Indian and Northern Affairs (INAC), has been the primary federal supporter of renewable energy development in Nunavut, most notably through its ecoENERGY for Aboriginal and Northern Communities Program, which provides funding to northern Aboriginal communities that want to develop renewable energy technology (RET) systems (AANDC, 2012). However, the role of this department has been diminished since the Canadian Northern Economic Development Agency (CanNor) was created recently to take over northern development programs in Canada (CanNor, 2012). Finally, the Department of Natural Resources Canada (NRCan), while playing only a minor role in Nunavut's renewable energy development, has developed national-scale renewable energy programs (through CanmetENERGY) that also apply to remote northern communities (Poissant et al., 2004; NRCan, 2009).

\section{Current Renewable Energy Policies in Nunavut}

Nunavut is not alone in this ongoing struggle to free itself of dependence on diesel-generated electricity. Other communities facing similar energy dependency have begun to explore cleaner and more cost-efficient alternatives, which include increasing their use of renewable energy technologies (St. Denis and Parker, 2009). In 2009, for example, Ontario created the Feed-in-Tariff (FIT) program, which encourages the development of renewable energy in Ontario as a form of investment (OPA, 2008, 2010; Smitherman, 2009; Branker and Pearce, 2010). Such policies and programs in many cases have proven to be excellent drivers for economic and sustainable development, and they lend themselves well to Aboriginal communities struggling to gain self-reliance and self-sustainability (Dignard-Bailey et al., 1998; McLaughlin et al., 2010; McDonald, 2011). Although these policy lessons are not directly transferable to Nunavut, they provide a potential means forward that has worked in another region of Canada.

However, as Nunavut is a very young territory and has been addressing a variety of policy issues, it has yet to focus on the need for renewable energy (GN, 2007a). Though the government did develop minor RET systems (e.g., solar panels, windmills) in various Nunavut communities in the 1980s and 1990s, there has been very little push since then to develop renewable energy policy and programs in the territory (Ah-You and Leng, 1999; Ascher, 2002; Nunavut Power, 2002; GN, 2007b).

In 2007, the GN $(2007 \mathrm{a}, \mathrm{b})$ published Ikummatiit: The Government of Nunavut Energy Strategy, which outlined various steps that should be taken with renewable energy (particularly hydropower); however, it has yet to follow up with an implementation plan.

Four years later, the report Paths to a Renewable North: A pan-territorial renewable energy inventory was released following a commitment from the three territorial premiers at the 2009 Northern Premiers Forum (Northern Vision, 2011). This report outlined current renewable energy practices in Nunavut and explained what future steps each territory would strive for with regard to renewable energy.

\section{METHODS}

\section{Data Collection}

In order to obtain an overview of current policy thinking in Nunavut, as well as challenges and opportunities for renewable energy, we interviewed 11 key government policy makers and consultants, using qualitative interviews to provide a glimpse into participants' opinions and perspectives (Patton, 1990). Respondents, who were chosen on the basis of their field of work within a northern remote community and renewable energy context, included representatives from the GN, policy directors from the Government of Canada, Qulliq Energy Corporation representatives, and renewable energy consultants. They were selected using the reputational approach developed by Laumann and Knoke (1987), which identifies respondents through personal contacts in the communities and recommendations of other researchers in the field. Snowball sampling following Erickson (1979) was also used: an initial contact in Iqaluit was chosen, and networks or chains of contact were developed from this first set of interviewees until a set termination criterion was met. While snowball sampling can lead to bias in opinions if a given pool of interviews is extensive (Laumann and Knoke, 1987), the limited renewable energy field in Nunavut produces a very small pool of respondents, thus limiting bias.

Each semi-structured interview (Patton, 1990) lasted from 30 to 60 minutes. The questions aimed to explore, through a policy lens, the current status of renewable energy policies and programs in Nunavut and the challenges and barriers faced by government departments as they explore the introduction of RETs in Nunavut.

\section{Data Analysis}

Since data were collected through qualitative interviews, most of the data analysis was qualitative as well. Case analysis, whereby data are organized by specific cases, groups or organizations for analysis (Patton, 1990), was used to explore and synthesize the involvement of various federal and territorial departments in renewable energy policy and programs in Nunavut. Content analysis was then used to identify the patterns, understandings, and insights that emerged from the interviews (Patton, 1990). We explored the major opportunities for and barriers to introducing renewable energy into Nunavut communities that respondents feel exist, as well as the short- and long-term actions that respondents anticipate their departments will take in the future. Finally, logical analysis (Patton, 1990) and 
pattern coding (Miles and Huberman, 1994) were used to explore the emergent underlying themes that were not apparent during content analysis.

\section{RESULTS}

\section{Federal and Territorial Government Involvement in Renewable Energy}

A number of federal and territorial departments, agencies, and Crown corporations are involved in renewable energy program and policy development in Nunavut. Interviews with representatives of these departments made it apparent that each department plays a different role with regard to energy in Nunavut.

CanNor, though still in the stage of establishing itself as a new federal agency, will likely play the largest federal role regarding renewable energy in Nunavut. The interview results established that the department will take a strong managerial role specifically in renewable energy, or as one interviewee suggested, the agency will act as the "conductor" for future projects, ensuring that projects move forward in a timely manner and that all federal departments are working together. Moreover, given CanNor's mission to focus on northern economic development, the agency will take over a number of northern programs and policies related to infrastructure and funding that were previously run by AANDC. Finally, respondents indicated that CanNor would focus largely on research and environmental assessments, rather than on renewable energy feasibility studies.

AANDC has largely been the face of the federal government in the North, but with the creation of CanNor, AANDC has begun to play a more passive role regarding renewable energy in Nunavut. However, respondents stress that the department has maintained a number of programs that support the development of RET systems in Nunavut. One such program is the ecoENERGY for Aboriginal and Northern Communities Program, designed to provide financial assistance to communities seeking to develop RETs. Like the CanNor representatives, AANDC respondents see their role with regard to renewable energy as more managerial; they act as watchdogs to ensure that federal RET programs are designed for all northern communities. One respondent explained:

We play a role in influencing the departments who are developing the programs and policies that deny the spending of money that could be related to energy. We influence them to ensure that the way they design their programs is applicable to the North. Generally what happens is that the departments will design policies and programs that are applicable to First Nations on reserve and forget about [AANDC's] role in the North.

Further to AANDC's involvement in the ecoENERGY program, the department has led the recent development of the Canadian High Arctic Research Station (CHARS), to be built in Cambridge Bay, Nunavut. Discussing the design of the station, a representative from AANDC explained, "We're looking at options for alternative energies as part of the development of the station in order to power the station." In their view, the long-term goal of integrating RETs would be to make the station "the prototype or the model, the pilot": if renewable energy technology works for them, then they can make it work for others.

AANDC respondents were clear that even though many of their department's previous roles will soon be given over to CanNor, the department will continue to maintain a number of programs and projects that will support renewable energy use in Nunavut.

In our discussion of renewable energy projects with NRCan representatives, it was evident that while their department plays an active role in natural resource development and energy policies, electricity is primarily under provincial and territorial jurisdiction. NRCan respondents, like those from AANDC and CanNor, explained that their department advises on renewable energy in Nunavut, setting up bilateral meetings between the premier of Nunavut and ministers from other energy-related departments. NRCan also monitors energy policy being developed at provincial and territorial levels and briefs the premier on such policies. Recently, an NRCan branch has also become involved in a National Working Group led by AANDC to share information and knowledge regarding renewable energy use in remote communities.

Since electricity is primarily a provincial and territorial responsibility, it was not surprising that the interviews indicated Nunavut's government and Crown agencies had the largest role in developing renewable energy policy and RET projects in Nunavut. This is especially true for the QEC, which controls the 27 stand-alone diesel plants and the handful of small RET systems in Nunavut. However, a QEC representative explained that it has been very difficult to explore RET projects because funding is hard to access, even for projects with life cycle economic benefits. The Government of Nunavut Energy Secretariat has continued to play an active role in developing renewable energy policy in Nunavut, as it hopes to increase accessibility to RET project funding.

\section{Challenges to Expanding Renewable Energy Policy and Programs in Nunavut}

In discussing the existing challenges to expanding renewable energy programs, policies, and projects in Nunavut, interviewees identified four major types of challenges related to (1) capacity, (2) cost, (3) technology, and (4) bureaucracy and institutions.

Capacity-Related Challenges: All respondents recognized a capacity gap, at both community and government levels, that impedes expansion of renewable energy programs and policies. As respondents noted, Nunavut communities face pressing social challenges, including mental 
health issues, drug and alcohol abuse, and gaps in education and basic literacy skills. Respondents believe that these problems have reduced the communities' capacity to address other issues, including energy. Even more importantly, they are not sure whether communities are prepared to take on RET projects, as they do not currently have individuals with the skills to install and maintain the systems.

In addition, there is a considerable strain on the educated and trained workers in Nunavut in the areas of renewable energy and policy development. A CanNor representative explained, "Labour is a real shortage and challenge in Nunavut communities. So... in some cases, talented, passionate, committed individuals... end up wearing eight or nine hats in the community." Ultimately, this situation creates an overwhelmed workforce in Nunavut communities, which often hinders the speed at which fundamental issues can be addressed.

However, capacity issues also exist within the federal and territorial governments. Many respondents explained that it is very difficult to keep government workers originally from the South working in Nunavut for an extended time. One respondent explained that "people are out there in Canada not necessarily wanting to move out to the North or willing to stay. That's one huge issue...there really seems to be a revolving door on a lot of these organizations." Another respondent also noted that it has been difficult to find individuals to work in the northern regional offices, where there seems to be a high turnover rate. As a result, according to representatives from various departments, the lack of continuity in the staff has often made it difficult to move projects forward.

Cost-Related Challenges: Development of any kind, including renewable energy development, is extremely expensive in the North. Many respondents discussed the high costs of developing infrastructure to support RET expansion and the up-front capital needed to purchase RET systems. Financing for these costs is very difficult to access in the North given the many other community issues that require funding more urgently. One respondent explained this dilemma,

The major challenges are not related to renewable energy. The major challenges are related to the fact that the overall challenges in the communities are so significant for the most part that you have to get through a pretty long list of pressing priorities before energy is going to rise to the top of the heap.

Respondents also explained that in Nunavut, given the remote and scattered nature of the energy landscape, often there are no economies of scale to develop RET systems. Respondents perceive that the payoff for developing a small-scale RET system in a community might be less than the cost of installing and maintaining the system (or, if the payoff did exceed the cost, the payback period would be too long). They explained that this perception has often been a deterrent to government investment in renewable energy.
However, another layer adds to the complexity of funding renewable energy projects in Nunavut. It is the GN's debt cap, which limits its ability to use life cycle arguments on major capital projects regardless of their technical and economic viability. A GN representative explained:

There is a 200 million dollar debt cap that is to limit the federal government's liability... If we defaulted on our debt, the federal government would have to pay it because [the GN] is a legal entity of the federal government. [But] the 200 million dollars is not enough to do anything. In fact, I think we're already at 120 million dollars in debt.

Added to this challenge, he explained, is the difficulty of distinguishing how the QEC fits into the debt cap. Although the QEC is legally a corporate entity, the federal government considers it an entity of the GN. Therefore, whatever debt the QEC accumulates is considered a debt of the GN. In the case of the Jaynes Inlet hydro plant, a system that QEC estimates will cost CAD \$200 million, finding financing options given the debt cap to take on such a project has been very difficult.

Technology-Related Challenges: Communities have had 50-100 years to fine-tune the use of diesel fuel, and thus, introducing new technologies such as RETs poses challenges related to technical inertia. Northern communities are settled with the current forms of energy generation, which makes it very difficult for new technologies to gain traction. Respondents from AANDC pointed out that often RETs are less well known in the North, and as a result, residents have less experience with the operation and maintenance of the systems.

Even if this challenge were overcome, the variability of both the weather and the number of hours of sunlight throughout the year means that energy supply from RETs is relatively intermittent in the North; therefore, RETS would require storage or diesel as a backup. Respondents often used a major simplifying assumption: that a single energy supply should be able to provide for all the loads. Since Nunavut is lacking in storage capability for energy from RETs, it is unlikely that diesel power can be completely replaced.

A further technological challenge discussed throughout the interviews is the lack of research and development being done on renewable energy in the relatively extreme climate of the North. For example, a respondent from NRCan explained that very few reliable wind measurements are available in Nunavut for a proper assessment of wind energy potential in the territory. Moreover, RET systems have not been properly designed or tested to withstand the harsh Nunavut climate, making them a somewhat questionable technology in the minds of some respondents.

Bureaucratic and Institutional Challenges: Within the realm of policy development, respondents discussed a number of challenges, past and present, to establishing and implementing renewable energy policies in Nunavut. The 
first challenge is the difficulty of bridging the interests of beneficiary organizations and government. Respondents explained that often both sets of organizations have varying priorities, which do not necessarily align with each other. As a result, tensions arise regarding what policies should be given first priority, and often renewable energy policy gets pushed down the priority list.

Another respondent adds that "utility companies have had bad luck with past projects, so they tend to press politicians by saying 'it doesn't work,' and ultimately politicians then don't support RETs." Moreover, respondents have noticed that often policies are looked at on a year-toyear basis, and politicians consider, "This is what I need this year to keep the lights on, to keep the cost under control." But they note that this reluctance to shift towards renewable energy may result from lack of familiarity with RETs. The consequence is that it has been very difficult to develop a collaborative sustainable renewable energy plan for Nunavut.

\section{Opportunities to Integrate Renewable Energy Policies and Programs in Nunavut}

Though many challenges were discussed throughout the interviews, respondents also indicated a number of opportunities. These opportunities were separated into five categories related to (1) funding, (2) technology, (3) partnerships and community engagement, (4) education, and (5) community development.

Funding Opportunities: The opportunity most acknowledged by all respondents was that as the price of diesel rises, and as RETs mature, renewable energy will likely become overwhelmingly economically beneficial to Nunavut. Furthermore, a respondent believed that:

If you can pitch renewable energy not as an environmental solution but as an environmental and economic driver for the community, in terms of creating jobs or developing capacity or generating income or all three... as well as being environmentally sound, then you have a chance of getting attention.

Respondents also discussed a number of financing options that the GN could explore to help fund RET projects in Nunavut communities, including rate-based financing, in which utility companies increase rates to earn a profit on higher costs; P3 financing, which involves a collaboration between public and private sectors to provide public services and capital financing; and finally, more overall federal government investments. Future work is necessary to investigate the economics of large-scale deployment of RETs in Nunavut.

Technological Opportunities: On numerous occasions, respondents explained that Nunavut's greatest opportunity with regard to RETs is the strong renewable resources that exist across the territory. However, as respondents indicated, the strength of these resources varies greatly depending on the geographic location of communities. Nonetheless, respondents believe that, in general, Nunavut has excellent solar resources in the spring and summer, typically constant winds year-round (though sometimes stronger in the winter), and strong hydro potential yearround. Some respondents also discussed the possibility of exploring ocean and marine energy through the use of tidal power, given the extremely high tides in Frobisher Bay.

Another technological opportunity that emerged was the ability of some communities to begin developing smallscale systems in order to perfect the technology and ensure that the "bugs" have been addressed. Often, these respondents supported an incremental approach to development; however, some held a different opinion.

One respondent explained that small-scale development might not be the best way to integrate RETs in Nunavut. In fact, he believed that "you have to have either five or six turbines in a given community or three or four communities all trying simultaneously; that way it makes sense to train people." His point was that a certain critical mass is necessary both to take advantage of economies of scale and to build appropriate capacity to make RETs work in Nunavut. An individual or small business cannot justify investing in capacity such as wind turbine maintenance unless there is demand for the services from an appropriately scaled array of systems that will provide employment to repay that investment in time, education, and financing. At low penetration rates of RETs, the overhead in terms of equipment and human time is prohibitive.

Partnerships and Community Engagement: Throughout the interviews, respondents indicated that one of the most important steps to successfully expanding RETs in Nunavut is to engage the communities and begin to build partnerships with a number of organizations. First, respondents explained, it is essential that community members become engaged in energy issues in Nunavut. In doing so, they will begin to take ownership of new RET projects. One respondent explained that in his experience working with northern communities, communities that established a "champion" to spearhead an RET project have been more successful than those that did not. Another respondent, noting the young demographic in Nunavut, suggested that as these young people mature, they might be more willing to take responsibility and provide leadership for community issues such as energy.

Respondents also recognized the need for the GN to develop partnerships with various organizations, including industry and universities. For instance, one respondent suggested that Nunavut begin to explore the opportunity to partner with a college in Prince Edward Island to provide a wind technician program to residents of Nunavut. Another suggested exploring a partnership with incoming mining companies, which could help foster renewable energy research or allow communities to share renewable energy being produced at the mining sites.

Education Opportunities: Respondents also expressed the need to develop education in Nunavut, both overall adult 
education and training specifically in renewable energy. One respondent explained that the territory must approach education in two phases. The first must focus on adult learning to increase the general education level of adult residents. The second phase must shift the focus to educating people for specific sectors, such as renewable energy. One way to support this second phase, as suggested by a handful of respondents, would be to provide courses through webinars and virtual classes at Arctic College in partnership with other technician programs at colleges across Canada.

Community Development Opportunities: A last area of focus that emerged from the discussion of opportunities was the need to develop green infrastructure within communities and to support more efficient use of energy across the territory. As one respondent explained, "Everybody should think about efficiency and conservation because those are going to be far more cost-effective than other renewable energy resources." Other respondents explained that energy efficiency could be achieved by simply using more energy-efficient appliances and light sources and by creating more energy-efficient habits within the communities. Yet the majority of respondents strongly believe that energy efficiency should be developed in conjunction with renewable energy.

\section{Anticipated Actions to Expand Renewable Energy in Nunavut}

After discussing the various federal and territorial departments' involvement in renewable energy in Nunavut, respondents were asked to outline actions that they anticipate their departments will be taking in the short and long terms. These actions are summarized in Table 1. Most respondents anticipate that their departments will continue what is already being done. For instance, interviewees from CanNor and AANDC expect that the role of the department will continue to be more management-oriented, focusing largely on funding support and knowledge sharing. Moreover, both CanNor and AANDC agree that energy will be a key issue in Nunavut's future. However, all respondents from AANDC added that the department's role will be greatly diminished because CanNor has taken over all the economic development and infrastructure programming.

Similarly, NRCan respondents expect that their department will likely continue to support programs provided by AANDC and CanNor. As one respondent explained, NRCan's focus "tends to be national in scope," and the department is not likely to establish any targeted northern programs. Yet they do anticipate that the department will continue to provide general input on renewable energy programs in the North.

The GN and its Crown agencies expect to play a growing and active role in developing renewable energy projects and policies across the territory. Moreover, the GN expects to begin an alternative and renewable energy study for all of Nunavut as part of the implementation of the 2007 Ikummatiit Nunavut energy strategy.

\section{DISCUSSION AND CONCLUSIONS}

\section{Perspective of Consultants and NGOs Working on North- ern Renewable Energy}

A number of consultants focus their work on exploring RET opportunities in the North and providing input and advice to policy makers. Therefore, we included such consultants in the interviews to help us understand the perspectives of those involved in northern renewable energy issues though outside government departments.

In general, the involvement of these respondents focused largely on wind and hydropower in Nunavut; however, some also had experience in solar studies in the North. Often, this work was accomplished in partnership with a federal government department, its goal either to assess the potential energy production of a renewable energy system in the North or to provide the government with a framework outlining the steps necessary to address renewable energy in the North effectively.

Like the respondents from the territorial and federal governments, the consultants and NGO representatives acknowledged the many technological challenges of using RETs in the North and the complexity of financing such projects. However, most added that from a non-government perspective, "governments need to support and encourage their utility [to support RETs]."

These respondents remain hopeful that as RETs mature, they could be successful in Nunavut. One respondent explained that eventually, the ideal situation to develop RETs in Nunavut would be one in which:

\begin{abstract}
You... get to a point where you have a cookie cutter approach so you don't have to re-engineer every project, but use... a standard engineering design just like you go and buy a generator. You should be able to go and buy a wind/diesel system where you just plug it in so you don't have to re-engineer it from scratch every time.
\end{abstract}

Respondents also proposed that the "Northern Territories take the bull by the horns...the way California [has done] with wind turbines and the way Ontario has been trying to do with the feed-in-tariff program." They believe that the federal government should provide more leadership and that the territory must establish the long-term goal of having sustainable energy systems in Nunavut communities.

One potential method to develop a "cookie cutter" renewable energy system for Nunavut is through research projects. These projects could be undertaken by either the federal government (e.g., NRCan) or by a university. An example is the Natural Sciences and Engineering Research Council of Canada's Collaborative Research and Training Experience Program (NSERC, 2012) grant for Distributed Generation for Remote Communities, awarded in 2011 to the University of Toronto and Queen's University. This program is designed to develop highly qualified personnel with expertise in off-grid electricity generation through the use 
TABLE 1. Anticipated short and long-term actions regarding RETs in Nunavut.

\begin{tabular}{|c|c|c|}
\hline Agency & Short-Term Actions & Long-Term Actions \\
\hline CanNor & $\begin{array}{l}\text { - Finish logistical set-up } \\
\text { - Continue infrastructure funding in the North } \\
\text { - Begin feasibility research for RETs in the North }\end{array}$ & $\begin{array}{l}\text { - Begin to move beyond the ecoEnergy for Aboriginal and Northern Communities program } \\
\text { and other similar programs established by AANDC (INAC) } \\
\text { - Begin to invest energy and money in the North to develop healthy and sustainable } \\
\text { northern economies } \\
\text { - Increase overall education in the field of renewable energy to create a specialized niche to } \\
\text { support RET development } \\
\text { - Develop responsive policy in the context of energy }\end{array}$ \\
\hline AANDC & $\begin{array}{l}\text { - Continue to fund RET projects on a proposal basis } \\
\text { - Provide input and advice on renewable energy } \\
\text { projects } \\
\text { - Develop a framework to provide a collaborative, } \\
\text { coordinated approach to addressing off-grid energy } \\
\text { issues in Aboriginal communities } \\
\text { - Continue to chair a working group that is developing } \\
\text { such a framework }\end{array}$ & $\begin{array}{l}\text { - Make the CHARS a model of renewable energy in Nunavut } \\
\text { - Create a trained RET workforce that could help communities install and maintain RET } \\
\text { systems }\end{array}$ \\
\hline NRCan & $\begin{array}{l}\text { - Continue to support northern renewable energy } \\
\text { projects led by AANDC through: (a) municipal } \\
\text { technological support and (b) economic expertise }\end{array}$ & - Support inter-provincial and inter-regional energy trade (i.e., transmission upgrades) \\
\hline $\begin{array}{l}\text { GN and } \\
\text { Agencies }\end{array}$ & $\begin{array}{l}\text { - Continue researching the feasibility of RETs } \\
\text { - Develop a renewable and alternative energy study } \\
\text { for Nunavut }\end{array}$ & $\begin{array}{l}\text { - If funding is available, begin to incorporate renewable energy into buildings } \\
\text { - Continue to explore and develop the Iqaluit hydro project } \\
\text { - Look at future possibilities for large-scale renewable energy }\end{array}$ \\
\hline
\end{tabular}

of clean energy technologies. The program will run pilot projects in remote communities, and the first pilot project is being developed in Iqaluit.

Gaps in Government Responsibilities with Regard to Renewable Energy in Nunavut

Upon completing the interviews with respondents from various departments and levels of government, it became apparent that some confusion exists within and across departments about what responsibilities each department has or should have with regard to renewable energy in Nunavut. Often, respondents provided conflicting responses about their own department's role in renewable energy efforts. Many respondents were also unaware of what responsibilities other departments had in developing renewable energy programs for Nunavut and providing funding for such programs. Often, the responses indicated that perhaps departments are working in isolation, rather than in collaboration with each other. However, as one respondent explained, collaboration among departments has increased since the creation of a National Working Group to share information and knowledge on renewable energy use in remote communities.

Increasing collaboration within and between departments is essential to ensure that future comprehensive renewable energy policies are developed. Energy in Nunavut is a complex issue that involves such diverse areas as infrastructure, environment, health, and economy. To ensure that renewable energy policies are successful, federal and territorial departments must work together and be aware of their respective responsibilities.

\section{Visibility and Accessibility of Funding for RET Projects}

In addition, the interviews pointed to the fact that remote northern communities have limited awareness of and access to funding for renewable energy projects. Federal government respondents alluded to some confusion regarding which departments were providing funding to the territorial government for renewable energy development, though they did not state this explicitly. A respondent from AANDC explained, "We facilitate a lot of discussions on what's happening up [North] and I guess there's a misconception that we can own the issue or that we fund everything directly. So people try to bring us in on quite a regular basis." This misconception carries across a number of departments in which funding and support for RETs was often believed to be the responsibility of other departments.

Furthermore, this confusion also exists at the territorial level: territorial government and Crown agencies also find it difficult to see where funding is available and how to access it. Discussions with territorial respondents made evident their frustration about where to find funding for RET projects in Nunavut. Moreover, respondents explained that when funding becomes available, there are often barriers to accessing it. For example, in 2007, AANDC established the ecoENERGY for Aboriginal and Northern Communities Program to provide financial support for communities that wish to reduce greenhouse gas emissions through clean energy projects (AANDC, 2012). While the program has been very successful in British Columbia, the interviews revealed that no Nunavut communities were able to participate in the program because each community was required to submit an energy audit, something that is not done in Nunavut because there are no qualified auditors. Nunavut could have capitalized on the ecoENERGY program by 
providing a small amount of funding to either train local residents in energy audits or bring in auditors from other regions. For Nunavut to make use of federal programs in the future, it is imperative that such relatively small enabling investments be developed in conjunction with federal programs.

Addressing issues of visibility and accessibility to funding are essential if Nunavut's goal is to develop renewable energy. Nunavut communities interested in developing RETs must have a clear point of contact within the federal and territorial governments for obtaining information about what funding programs exist and how they can access the funding.

\section{Addressing Education Gaps in Nunavut}

As previously discussed, respondents perceived an education gap in Nunavut, both within general adult education and in a specialized renewable energy education context. Although improving adult education in Nunavut is a complex issue, it is an essential step towards developing capacity that will support renewable energy development and the related jobs.

Respondents suggested that one way to develop a niche specialized in renewable energy education would be for the Arctic College and Trades School to partner with other Canadian universities and colleges in order to provide courses through webinars, virtual courses, and data sharing. For example, St. Lawrence College recently developed the Energy Systems Engineering Technology Diploma, which prepares students to work within the field of renewable energy and energy efficiency in residential and commercial buildings (ESET, 2010). In addition, because of the enormous growth of the photovoltaic industry in Canada, there was an increased demand for high-quality research in solar systems design and optimization in realistic (and sometimes extreme) Canadian outdoor environments. To answer this need, a partnership has formed the Open Solar Outdoors Test Field (OSOTF), which is housed at the Sustainable Energy Applied Research Centre (SEARC) at St. Lawrence College (Appropedia, 2012; Pearce, et al., 2012). The data gathered by OSOTF, which will be available to all researchers and to the general public, can directly assist in optimizing photovoltaic systems both in Nunavut and throughout Canada.

\section{Necessary Future Steps}

As previously indicated, a number of challenges and gaps exist across departments and governments with regard to developing renewable energy policy in Nunavut. The most obvious is the overwhelming organizational gap in program delivery and development. A suggestion is to create a federally led group that coordinates renewable energy program development and delivery for remote northern communities like those in Nunavut. This will ensure that there is a single group overseeing renewable energy programs and policies in Nunavut, as well as managing other departments and organizations involved in renewable energy development. Moreover, this provides communities with a clear point of contact for future RET projects, ensuring that they are aware of the application process and requirements.

Moreover, establishing a lead group for renewable energy policy and program development in Nunavut will help develop a formal economic analysis of electricity costs and subsidization in the territory. This is especially important in Nunavut because the true cost of electricity is difficult to assess, which makes it difficult to determine how the cost of renewable energy compares to that of diesel-generated electricity. This group could have part of its leadership from NRCan. The role of NRCan in RETs in Nunavut could be substantial, not only to tie together the necessary technical research, but also to provide leadership in the Council of Energy Ministers, which has a federal-provincial-territorial group that meets on energy policy issues and does research. Using the existing Council of Energy Ministers and all of its working groups is perhaps one of the most promising conduits for establishing more aggressive RET policy mechanisms in Nunavut.

Recent work has shown that RET systems are technically viable in Nunavut (McDonald et al., 2012) and can be economically viable when viewed from a life-cycle perspective as an investment (Pearce et al., 2009). For example, very preliminary calculations based on current prices for materials and electricity show that a photovoltaic system in Iqaluit with an installed cost of $\$ 6.50 / \mathrm{W}$ would provide electricity to the community at about $51 \not / \mathrm{kWh}$, assuming no overhead, which is similar to the current diesel-generated rates of $52 \phi / \mathrm{kWh}$ (CBC, 2011). This cost represents an enormous markup of first costs of PV systems, as the global market for the PV modules themselves is well under $\$ 1 / \mathrm{W}$, and this fact considerably reduces the levelized cost of electricity (Branker et al., 2011). However, since electricity subsidies in Nunavut are multi-layered and complex, the true cost of electricity in any community is difficult to assess (GN, 2007a, b). Therefore, an important first step for this lead group is to perform a full life cycle economic analysis of the current diesel power system to determine the true cost of electricity in Nunavut in order to make a fair comparison with the potential renewable electricity prices. Next, a full life cycle economic analysis of renewable energy in Nunavut should be completed in order to determine the precise cost of an RET system and levelized costs of renewable electricity. These two economic assessments will produce a precise picture of the economic viability of renewable energy (which is already clear from preliminary analysis, but has not been quantified), providing motivation for the territory to shift away from diesel-generated electricity.

\section{ACKNOWLEDGEMENTS}

The authors would like to thank the participants of the study, TD Canada Trust, and NSERC for funding this project and the Government of Nunavut for their support throughout the project. 


\section{REFERENCES}

AANDC (Aboriginal Affairs and Northern Development Canada). 2012. ecoENERGY for Aboriginal and Northern Communities Program 2011-2016. Ottawa: AANDC. http://www.aadncaandc.gc.ca/eng/1100100034258/1100100034259.

Ah-You, K., and Leng, G. 1999. Renewable energy in Canada's remote communities. Ottawa: Natural Resources Canada. http://fnbc.info/sites/default/files/documents/Renewable $\% 20$ Energy\%20in\%20Remote\%20Communities.pdf.

Appropedia. 2012. Open solar outdoors test field. http://www. appropedia.org/Open_Solar_Outdoors_Test_Field.

Ascher, A. 2002. North wind: Nunavut and Yukon are hoping wind turbines will reduce dependency on diesel plants. Alternatives Journal 28(4).

Branker, K., and Pearce, J.M. 2010. Financial return for government support of large-scale thin-film solar photovoltaic manufacturing in Canada. Energy Policy 38(8):4291 - 4303.

Branker, K., Pathak, M.J.M., and Pearce, J.M. 2011. A review of solar photovoltaic levelized cost of electricity. Renewable and Sustainable Energy Reviews 15(9):4470-4482.

CanNor (Canadian Northern Economic Development Agency). 2012. Program information. Ottawa: CanNor. http://www. cannor.gc.ca/pr/index-eng.asp.

CBC (Canadian Broadcasting Corporation). 2011. Electricity in Nunavut. CBC News, April 9. http://www.cbc.ca/news/canada/ story/2011/04/09/f-territory-energy-profile-nunavut.html.

Chung, T., and Hyslop, C. 2008. The Arctic: A Canadian parliamentary chronology. Ottawa: Parliament of Canada. http:/www.parl.gc.ca/Content/LOP/ResearchPublications/ prb0811-e.htm.

Creery, I. 1983. The Inuit (Eskimo) of Canada. London: Minority Rights Group.

Crowe, K.J. 1991. A history of the original peoples of northern Canada, rev. ed. Montreal: Arctic Institute of North America.

Dignard-Bailey, L., Martel, S., and Ross, M.M.D. 1998. Photovoltaics for the North: A Canadian program. Varennes, Quebec: Natural Resources Canada.

Egeland, G.M., Pacey, A., Cao, Z., and Sobol, I. 2010. Food insecurity among Inuit preschoolers: Nunavut Inuit Child Health Survey, 2007-2008. Canadian Medical Association Journal 182(3):243-248.

Erickson, B.H. 1979. Some problems of inference from chain data. Sociological Methodology 10:276-302.

GC (Government of Canada). 1993. Nunavut Act: An Act to establish a territory to be known as Nunavut and provide for its government and to amend certain Acts in consequence thereof. S.C. 1993, c. 28. Ottawa: Department of Justice. http://lawslois.justice.gc.ca/eng/acts/N-28.6/index.html.

- 2010. Government of Canada promotes Inuit involvement in resource development. Iqaluit: CanNor. http://news.gc.ca/ web/article-eng.do?nid=558189.

GN (Government of Nunavut). 2002. Meeting Nunavut's energy needs: Structures and strategies for energy self-reliance. Ikuma II Report. Iqaluit: Nunavut Economic Forum.
- 2007a. Ikummatiit: The Government of Nunavut energy strategy. Iqaluit: Department of Executive and Intergovernmental Affairs.

- 2007b. A Discussion Paper for Ikummatiit: An energy strategy for Nunavut. Iqaluit: Energy Secretariat.

_. 2008a. Culture. Iqaluit: Government of Nunavut. http:// www.gov.nu.ca/files/Culture.pdf.

—. 2008b. Devolution. Iqaluit: Department of Executive and Intergovernmental Affairs. http://www.eia.gov.nu.ca/en/ Devol.aspx.

- 2009. Nunavut maternal and newborn health care strategy 2009-2014. Iqaluit: Department of Health and Social Services. 2010a. Fiscal and economic outlook. Iqaluit: Department of Finance Nunavut.

- 2010b. Government policies. Iqaluit: Dept. of Community and Government Services, Government of Nunavut. http:/ www.gov.nu.ca/en/Policies.aspx.

—. 2010c. Energy Policy Division. Iqaluit: Department of Executive and Intergovernmental Affairs. http://www.eia.gov. nu.ca/en/Energy.aspx.

—. 2010d. Nunavut Energy Management Program policy. Iqaluit: Department of Community and Government Services. http://www.gov.nu.ca/policies/nep.pdf.

- 2010e. Petroleum Products Division. Iqaluit: Department of Community and Government Services. http://cgs.gov.nu.ca/ en/petroleum.aspx.

GNWT (Government of Northwest Territories). 2008. Electricity rates for 1,000 kW.h in North America (in cents per kW.h). Yellowknife: Centre for Geomatics, GNWT.

- 2009. Alternative Energy Technologies Program. Yellowknife: Department of Environment and Natural Resources. http://www.enr.gov.nt.ca/_live/pages/wpPages/ aetp.aspx.

GY (Government of Yukon). 2008. Yukon Renewable Energy Resource Map Viewer Jump Page. Whitehorse: Department of Energy, Mines and Resources. http://www.energy.gov.yk.ca/ renewable_energy_map_viewer_jump.html.

Laumann, E.O., and Knoke, D. 1987. The organizational state: Social choice in national policy domains. Madison: The University of Wisconsin Press.

McDonald, N.C. 2011. Exploring local Nunavut perspectives on renewable energy expansion. Public Sector Digest, April 1.

McDonald, N.C., and Pearce, J.M. In press. Community voices: Perspectives on renewable energy in Nunavut. Arctic.

McDonald, N.C., Nguyen, H.T., and Pearce, J.M. 2012. Technical feasibility of renewable electricity generation in Nunavut. In: Tiwari, M.D., and Vaish, A., eds. Green energy. Aalborg, Denmark: River Publishers. 41-74.

McLaughlin, D.V.P., McDonald, N.C., Nguyen, H.T., and Pearce, J.M. 2010. Leveraging photovoltaic technology for sustainable development in Ontario's First Nations communities. Journal of Sustainable Development 3(3):3-13.

Miles, M.B., and Huberman, A.M. 1994. Qualitative data analysis: An expanded source book. Beverly Hills: Sage Publications.

National Energy Board. 2011. Energy use in Canada's North: An overview of Yukon, Northwest Territories, and Nunavut. Energy facts March 2011. Ottawa: National Energy Board. 
NCLA (Nunavut Land Claims Agreement Act). 1993. An Act respecting an Agreement between the Inuit of the Nunavut Settlement Area and Her Majesty the Queen in right of Canada. 1st Reading, June 10, 1993, 34th Parliament, 3rd Session, 19881993. Ottawa: Department of Justice. http://aws-lois.justice. gc.ca/PDF/N-28.7.pdf.

Northern Vision. 2011. Paths to a renewable North: A panterritorial renewable energy inventory. Iqaluit: Northern Premiers Forum. http://www.anorthernvision.ca/documents/ RenewableEnergyInventoryEN.pdf.

NRCan (Natural Resources Canada). 2009. Renewables. Varennes: CanmetEnergy. http://canmetenergy-canmetenergie.nrcanrncan. gc.ca/eng/renewables.html.

NRI (Nunavut Research Institute). 2012. Research licencing applications. Iqaluit: NRI. http://www.nri.nu.ca/apps/ authoring/dspPage.aspx?page=applications.

NSERC (Natural Sciences and Engineering Research Council of Canada). 2012. Collaborative Research and Training Experience Program. Ottawa: NSERC. www.nserc-crsng. gc.ca/Professors-professeurs/grants-subs/CREATEFONCER_eng.asp.

NTI (Nunavut Tunngavik Incorporated). 2008. Nunavut Adult Learning Strategy. Iqaluit: Department of Health and Social Services.

- 2010. Recruitment and retention of Inuit nurses in Nunavut. Report prepared by Aarluk Consulting Inc., March 2009, on behalf of NTI. Iqaluit: Department of Health and Social Services.

Nunavut Power. 2002. Wind power generation. Iqaluit: Government of Nunavut.

OPA (Ontario Power Authority). 2008. Facilitating the development and use of renewable energy and enabling 2010 and 2025 renewable targets. Toronto: OPA. http://www.powerauthority. on.ca/sites/default/files/page/6448_E-2-2_corrected_080505_ mm_.pdf.

—. 2010. FIT Program. Toronto: OPA. http://fit.power authority.on.ca/fit-program.

Patton, M.Q. 1990. Qualitative evaluation methods, 2nd ed. Newbury Park: Sage Publications Inc.
Pearce, J.M., Denkenberger, D., and Zielonka, H. 2009. Accelerating applied sustainability by utilizing return on investment for energy conservation measures. International Journal of Energy, Environment and Economics 17(1):61 - 80.

Pearce, J.M., Babasola, A., and Andrews, R. 2012. Open solar photovoltaic systems optimization. Proceedings of Open 2012, the 16th Annual National Collegiate Inventors and Innovators Alliance Conference, 22-24 March 2012, San Francisco, California.

Poissant, Y., Thevenard, D., and Turcotte, D. 2004. Performance monitoring of the Nunavut Arctic College PV System: Nine years of reliable electricity generation. Varennes, Quebec: CanmetENERGY.

QEC (Qulliq Energy Corporation). 2005. Qulliq Energy Corporation: Annual Report. Iqaluit: QEC.

—. 2011. April 2011 rate schedule. Iqaluit: QEC.

Sivummut Economic Development Strategy Group. 2003. Nunavut economic development strategy: Building a foundation for the future. Iqaluit: Nunavut Economic Forum.

Smitherman, G. 2009. Bill 150, Green Energy and Green Economy Act, 2009. Toronto: Legislative Assembly of Ontario. http://www.ontla.on.ca/web/bills/bills_detail.do?locale $=$ en $\&$ BillID $=2145$.

St. Denis, G., and Parker, P. 2009. Community energy planning in Canada: The role of renewable energy. Renewable and Sustainable Energy Reviews 13(8):2088-2095.

St. Lawrence College. 2012. Energy Systems Engineering Technology Program. Kingston: St. Lawrence College. http:// www.stlawrencecollege.ca/index.aspx?iPageID=139\&iMenuI $\mathrm{D}=6$ \&prog $\mathrm{Id}=555$.

U.S. EPA (U.S. Environmental Protection Agency). 2002. Health assessment document for diesel engine exhaust. EPA/600/890/057F, 2002. Washington, D.C.: Office of Research and Development, National Center for Environmental Assessment.

Wonders, W.C. 2003. Nunavut: Canada's new Arctic territory. In: Wonders, W.C., ed. Canada's changing North, rev. ed. Montreal: McGill-Queen's University Press. 344-347. 